\title{
Reflecting the Mindset of Students' Pursuing Higher Education During Post-COVID-19 Lockdown Scenario in India: With Special Reference to West Bengal
}

\author{
Sumi Karmakar \\ M.Phil. Scholar, University of Calcutta,India \\ Abhijeet Bag \\ Assistant Professor, Dept. of Commerce, Cooch Behar Panchanan Barma University,India
}

\begin{abstract}
Lockdown, a term that gives nightmares to many these days but for many it is a major bliss. Apart from a section having earnings even during lockdown period and sections not having any earnings during the lockdown there is another particular section and probably one of the most important ones i.e. the present youth generation and our upcoming future generation which was also a part of this lockdown scenario. This study is based on the mind set of such upcoming future human resources of our society, with the objectives of analyzing the impact of online teaching on the students and to examine whether there exists any relation among the mindset regarding post lockdown scenario. For the study, we have used descriptive statistics and non-parametric test like Chi-square using SPSS package and our overall result denotes that there exists significant relationship among area, connectivity and online teaching availing by the students.
\end{abstract}

Keywords: Infectious diseases, Lockdown, Higher Education, Hypothesis Testing

DOI: $10.7176 / \mathrm{JEP} / 11-16-13$

Publication date:June 30th 2020

JEL: $C 12, I 10, I 23, Y 10$

\section{INTRODUCTION:}

The sudden outbreak of a new virus that began in the Central Chinese city of Wuhan ${ }^{\mathrm{i}}$ shook the entire world named as the Corona Virus and was declared as a pandemic. The name was coined by June Almeidai ${ }^{\text {ii }}$ and David Tyrrelliii who first observed and studied human Corona Viruses. Corona Virus is a group of related RNA virus that causes disease in mammals and birds. In humans these viruses causes infectious disease in form of respiratory tract infection that can range from mild to lethal. The corona virus family has many types that affect people. Some cause the common cold while others originating in bats, camels and other animals have evolved into more severe illness such as SARS (Severe Acute Respiratory Syndrome) or MERS ( Middle East Respiratory Syndrome). The UN health agency announced on $11^{\text {th }}$ of February, 2020 that 'COVID-19' will be the official name of the deadly virus from China.Tedros Adhanom Ghebreyesus, the chief of World Health Organization said that 'Co' stands for 'Corona', 'Vi' for 'Virus' and 'D' for 'Disease' while '19' was for the year as the outbreak was first identified on $31^{\text {st }}$ December.

With the enhancement of the life threatening risk caused due to Corona Virus India's Prime Minister declared a Janta Curfew on the $22^{\text {nd }}$ of March, 2020. It was an appeal to the Indian Citizen to stay completely locked down for a day and surprisingly it was a huge success. But the next declaration by honorable Prime Minister on Tuesday night $24^{\text {th }}$ of March, 2020 gave a shock to all Indian Citizen. It was the first lockdown as declared by Prime Minister Narendra Modi for a period of 3 (Three) weeks to be affected from the midnight of $24^{\text {th }}$ of March, 2020 by giving Indians less than four hours' notice. This was a matter of shock for the ones those were away from their home either for educational purpose or for work purpose. The worst affected ones were the labor class people. The lockdown was further extended for 14 days up to $3^{\text {rd }}$ of May, 2020. As the number of Covid-19 cases in the country breached the $40,000^{\text {iv }}$ - mark lockdown 3.0 began i.e. the second extension for two weeks up to $17^{\text {th }}$ of May, 2020. But, with every extension came several other declarations by the honorable Prime Minister. To control the spread of virus several precautionary measures were suggested by the health authorities leading to significant change in cultural social and day to day behaviors. Social distancing, wearing masks in public places, frequent washing of hands for at least 20 seconds, avoiding mass gatherings etc.

Also decisions like work from home, online teaching facilities were matters that were emphasized by using the available internet facilities like Zoom, Google meet, Cisco WebEx, Skype etc. The Corona Virus pandemic changed the entire nations map with RED, ORANGE, and GREEN colored zones. This issue further led to the declaration of lockdown 4.0 from $18^{\text {th }}$ of May up to $31^{\text {st }}$ of May, 2020.The situation was further worsened by the devastating Super Cyclonic storm 'AMPHAN' that caused widespread damage in Eastern India, West Bengal in specific and which made a landfall on $20^{\text {th }}$ May in West Bengal leaving West Bengal into a condition that became a terror for the State Government in terms of the ways leftover to recover the loss caused. During the 
period of lockdown all kinds of educational institutions were given instruction to remain close until and unless the situation comes under control.

The mid semester examination was put on hold. All other examinations came to a pause. The sudden declaration of lockdown put a sudden stop to the education they were availing either from the institutions or from private tutors. Though government declarations were made to start to approach students by online medium of teaching but how much successfully it was possible is still a question mark.

Students with good financial background and proper internet facility could avail such educational facilities but the unprivileged ones were with no words left to be expressed. Further, the after effect of ' $A M P H A N$ ' totally ruined the entire scenario of West Bengal with uprooted trees almost everywhere damaging houses, electric posts and lives as well. Even many parts of West Bengal were without electricity for more than a week and the internet connectivity got ruined totally. The electricity and network problem is still prevalent in those worst affected areas.

\section{REVIEW OF LITERATURE:}

On the basis of the effectiveness of our upcoming youth generation availing the higher education, the researchers have gone through so many literatures at international, national and regional level. After a minute screening of all available literatures, the researcher has mentioned some pertinent and relevant literatures below:-

Bag, Abhijeet (2018) in his study mentioned the working conditions of teachers in higher education institutions in West Bengal. The author used many statistical tools to find out the significance differences among the teachers' stress and salary structure, etc. The study concludes that the working conditions were very alarming.

Choudhury, S et.al(2020) conducted a study on the tourism Industry in India and the financial impact on such industry by analyzing the financial impact on tourism industry with reasons why such industry is likely to be the most sufferer ones than any other industry due to COVID-19 pandemic. The study indicated the huge loss of 125 trillion that was suffered by the tourism industry in the year 2020 along with a 40 percent decline in tourism sector over 2019 together with a potential job loss of 38 million which is 70 percent of the total work force. It also revealed the tourism industry to get mostly dysfunctional due to the complete lockdown situation.

Kolte, A (2020) mainly dealt on challenges faced by employees of Mumbai region because of working from home during lockdown period due to COVID-19. The study focused on the frame of mind of employees working from home, to determine the actual challenges faced by them, and understand how they overcome the challenges to find out future viewpoints of employees. The result of such study showed that majority of respondents (employees) have mindset that they can work from home as per their flexible schedule and 100 percent of the respondents are facing challenges some way or the other while working from home during the lockdown period.

Prasad, K et.al (2020) have studied the association among COVID-19 parameters (workplace isolation, lack of peer advice, lack of communication, family distractions and role overload), occupational stress and employee performance in the Agricultural Sector and to study if there are gender and age differences that influence the performance of employees in the Agricultural Research Sector. The study concluded that occupational stress factors and COVID-19 parameters are common to both male and female and are statistically significant and good predictors. But there was a need for further research on different other sectors, like stress factor was to be considered during this COVID-19 scenario.

Shaikh, A et.al (2020) threw some light on the impact of the lockdown on India's informal sector was based on comparative study of such informal sectors in India as well as the study focused on analysis of revenue during lockdown and the impact of such lockdown in cash flow at market place and on the availability of insufficient stock in the market. The study reflected a mixed response from different form of small traders who were mostly affected by the lockdown and also majority of respondents agreed to the fact that non availability of customer s led for no stock flow of product. The further revelation was that among the affected small traders the street vendors suffered the most of the loss.

Shukla, A et.al(2020) have conducted a study on how people were coping with the stress of lockdown and analysis of the level of stress among children's adults and old person revealed that children's demanded more attachment with their parents. The study further reflected the need of mental calmness to deal with such a challenging situation.

Singh, M. K et.al (2020) have focused on the impact of COVID-19 pandemic on the working culture of IT professionals of Bangalore, Karnataka (India). The study focused on the dramatic workplace transformation i.e. work from home, physical distancing, online education and virtual meetings as the 'New Normal' of life and its impact on the IT professionals as well as examined the emerging trends due to wider acceptance of work from home. The final conclusion of the study reflected towards the new normal i.e. new ways of living for survival of human being in the present situation along with the different opportunities and Challenges that will come along the way. 


\section{RESEARCH GAP:}

On the basis of above review of available literatures, the we found that, different sections struggling each day to make situations better amongst such pandemic, after storm affects, the study is specifically based on our upcoming youth generation, the generation, that is going to contribute to our economic structure in different ways. The mindset (refers to a person's thoughts and beliefs that give a shape to their thought habits, affecting their way of thinking, feeling as well as their actions) of our upcoming human resources in form of our present students pursuing higher education is at stake.

The students became so burdened with the pressures of their awaited exams, with no physical classes held, and the COVID-19 outbreak that several protests started all over the social networking sites bullying educational system, online teaching, posting banners with messages dedicated for the ministers to remind them about the democratic rights that they possess, with online petition being signed by many for not giving exams and getting promoted on the basis of previous results etc. and many more such steps is being taken.

The continuous buzz of Corona virus pandemic along with Super Cyclonic Storm ' $A M P H A N$ ' devastating result impacted their mental condition miserably that they lost the power of thinking of their upcoming future.

Hence, there are no such literatures exist on the students' mind-set in this lockdown scenario. So, the researchers have shown interest to engage them self into this interesting as well as challenging and very sensitive research venture.

\section{OBJECTIVES OF THE STUDY:}

The objectives of the study are:

(i) To analyse the impact of online teaching on the students pursuing higher education.

(ii) To examine whether there exist any relation among the mindset of students regarding post lockdown scenario.

\section{HYPOTHESIS OF THE STUDY:}

$\mathbf{H}_{01}$ : There is no relationship between the area where the students stays and the availability of the online class facilities.

$\mathbf{H}_{02}$ : There is no relationship between the internet connection and the availability of online class facilities.

$\mathbf{H}_{03}$ : There is no relationship between the opinions of students regarding the online class facilities and the availability of online class facilities.

\section{DATABASE AND METHODOLOGY:}

The present topic deals with data sources and methods used to conduct the study. The size of the sample, its selection, designing of questionnaire and techniques used to analyze the responses have been dealt with in this portion. It is the most crucial part of any meaningful research. A plan has to be thought of and implemented to achieve specific results. In order to reach the conclusions, ideas have to be organized. It provides broad insights into the procedure adopted by the researchers in conducting the research. It comprises various components such as identifying data collection methods, arriving at tools of data analysis, etc.

The study is descriptive ${ }^{1}$ and exploratory ${ }^{2}$ in the sense that it is inclined towards the identification and description of various challenges and mental situation of the students'. The research aims to bring out the impact which these challenges or barriers have on the life related to education of students' of higher education. The scope of the study was limited to the general degree colleges and universities of West Bengal.

\subsection{Sample Design:}

This research utilizes a survey design. "A survey design provides quantitative or numeric description of trends, attitudes, opinions of a population by studying a sample of the population" (Creswell, 2003) ${ }^{3}$. In most of the studies it becomes impossible to study the entire universe. In such a situation the only alternative available is to go for sampling. The present study is also of the same nature. According to Manheim $(1977)^{4}$, "a sample is a part of the population which is studied in order to make inferences about the whole population."

\subsection{Data Sources:}

The present section deals with the sources of primary and secondary data. The target population was the students

\footnotetext{
${ }^{1}$ A descriptive study describes the characteristics of the phenomenon being studied. It does not answer how when and why the characteristics occurred, rather it addresses the 'what' question. The main goal of this type of research is to describe the data and its characteristics regarding what is being studied.

${ }^{2}$ Exploratory research seeks to find out how people get along in the setting under question, what meanings they give to their actions and what issues concern them.

${ }^{3}$ Clark, V. L. P., Creswell, J. W., Green, D. O. N., \& Shope, R. J. (2008). Mixing quantitative and qualitative approaches. Handbook of emergent methods, 363

${ }^{4}$ Manheim, H. I. (1977). Social Research; philosophy and methods.
} 
availing the higher education in general degree colleges and universities of West Bengal, India. Using the convenient sampling technique, questionnaire was distributed using email and google form during the month June of 2020. Number of responses received was 372 out of which 27 were incomplete. The final sample size for the research is 345 . The secondary data were collected from different research article, magazines, reports, newspaper, websites, government orders, etc.

\subsection{Research Instrument for Primary Data Collection:}

The present study which is basically empirical in nature makes extensive use of the primary data gathered through a survey with the help of a well-structured questionnaire. Fink (2006) ${ }^{1}$ observed that "Surveys are used to collect information from or about people to describe, compare or explain their knowledge, feelings, values and behaviour". The nature of questions was decided after communicating with few college and university students. Various factors which ware impacting the students in this lockdown scenario were included in the questionnaire. Apart from demographic factors, a number of questions were related to the present internet platform the students were using for online learning in this lockdown period. Questions were dichotomous, categorical as well as nominal in nature.

\subsection{Data Collection Method:}

For the purpose of reaching to the conclusion the researchers followed questionnaire method to collect primary data. The questionnaire was mailed electronically as well as sent by using google forms to the respondents and reminders were sent as well as telephonic requests were also made. The overall response was quite satisfactory. On the whole, online method remained the primary contact method for data collection.

\subsection{Analytical Tools Used:}

This section deals with the methodological tools used for analyzing the primary and secondary data. In the present study, responses were collected, coded and tabulated in IBM SPSS package. For analyzing the data both simple and advanced statistical tools have been used like Simple Percentages, Cross Tabulation, and Chi-square Test.

\section{ANALYSIS OF RESULTS:}

The analysis of results are subdivided into two parts:(i) Graphical analysis(ii) statistical analysis.

\subsection{Graphical Analysis}

The data analysis section deals with the various parameters which are in the questionnaire to analyze the mindset of students' pursuing higher education. The analysis of the results is presented in the following figures and tables.

Figure 1: Opinion on COVID 19

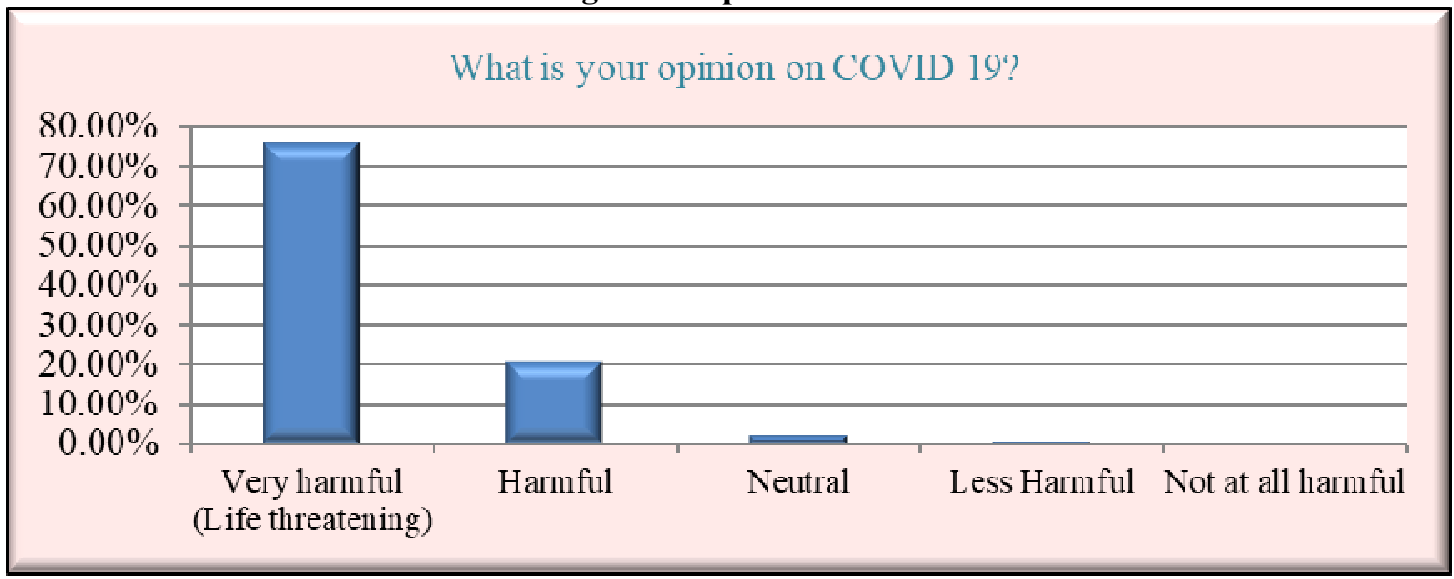

\section{Source: Own estimates from tabulated data}

From the above Figure it is relevant that majority of the students' i.e. $76 \%$ of the sample size opinion indicate such infectious disease (COVID-19) to be very harmful i.e. Life threatening.

\footnotetext{
${ }^{1}$ Fink, A. (2015). How to conduct surveys: A step-by-step guide. Sage Publications.
} 


\section{Figure 2: Type of Internet Facilities}

What type of Intemet facility/facilities you avail mostly for your education purpose?

PDF/PPT/Word Files available in

Google Class room

Zoom/Google meet

YouTube

Facebook/WhatsApp/Instagram/Twitter

Email

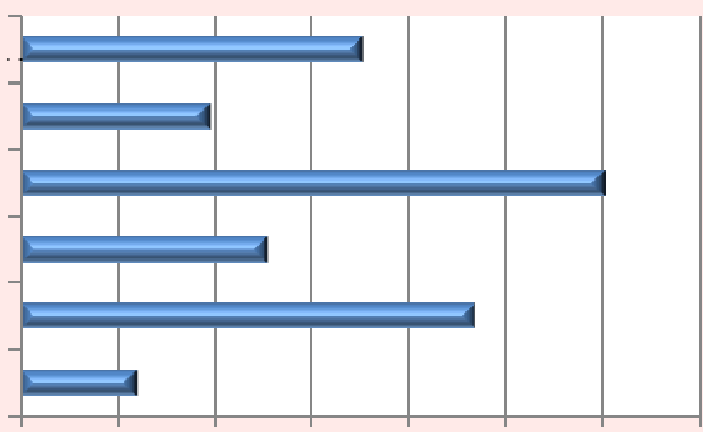

$\begin{array}{lllllllll}0 \% & 5 \% & 10 \% & 15 \% & 20 \% & 25 \% & 30 \% & 35 \%\end{array}$

\section{Source: Own estimates from tabulated data}

Figure 2 indicates that more than Facebook/WhatsApp/Instagram/Twitter (23\%) majority of students are availing Zoom/Google meet facilities for pursuing their online studies i.e. $30 \%$ of the sample size.

\section{Figure 3: Opinion on Reopening of Institutions}

What is your opinion on reopening of educational institution after the lockdown period?

Should never open till the vaccine is available for curing COVID 19

Will not go even if it opens in this situation

I don't want it to open till COVID 19 continues

Eagcrly waiting

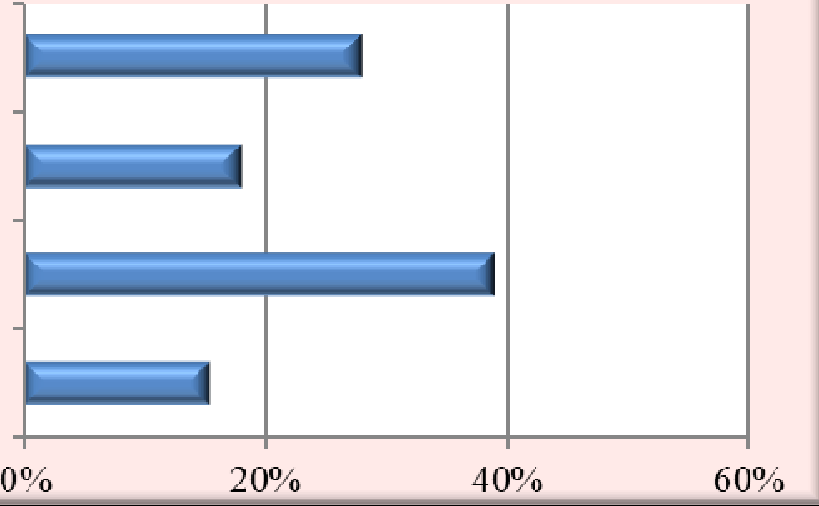

\section{Source: Own estimates from tabulated data}

From the above Figure it is quiet relevant that least of the students i.e. $15 \%$ are found to be eagerly waiting for the reopening of the educational institutions whereas many have supported the reopening of educational institutions only after the availability of COVID-19 vaccine. But majority is in favour of reopening of educational institutions only after a proper end/cure to the COVID-19 virus i.e. $39 \%$ of the total samples.

Figure 4: Opinion on Conducting Examination

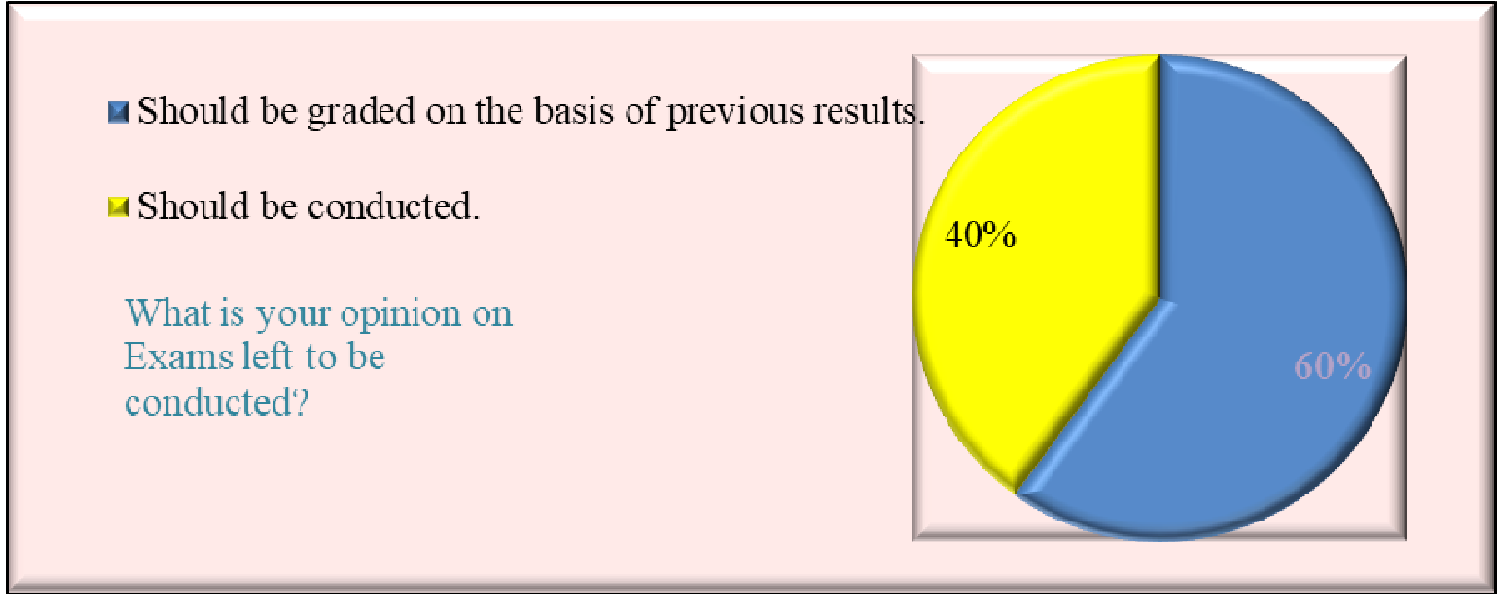

\section{Source: Own estimates from tabulated data}

The above Figure is a clear indicator that there exist a $60: 40$ ratio, where the majority i.e. 60 percent of the total samples (total number of student's response) wish to be graded on the basis of previous results. 
Figure 5: Mental Condition of students'

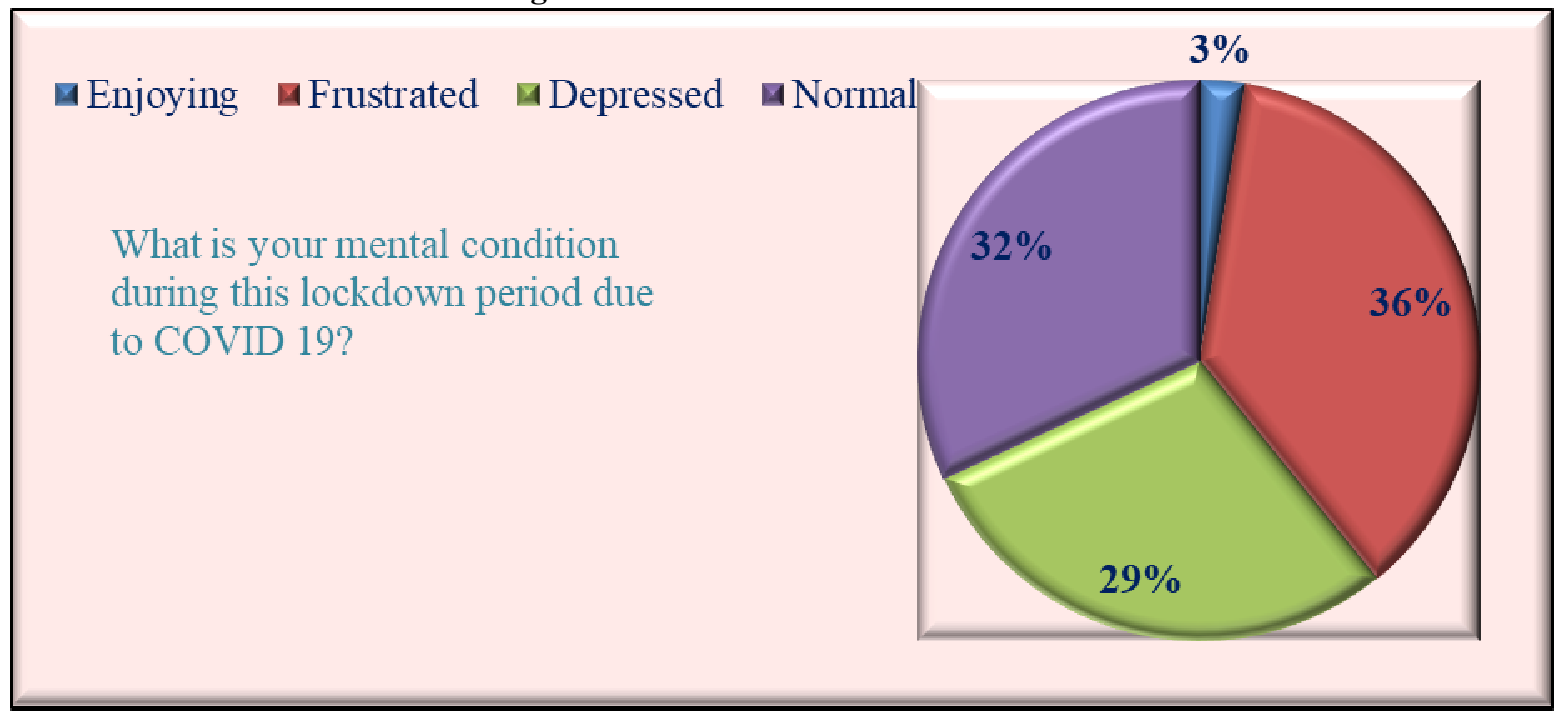

\section{Source: Own estimates from tabulated data}

Figure 5 clearly reflects though least percentage of students are Enjoying during the lockdown period but their percentage of frustrated mindset have overcome the Normal mindset by $4 \%$.

Figure 6: Opinion on Online and Class room Teaching

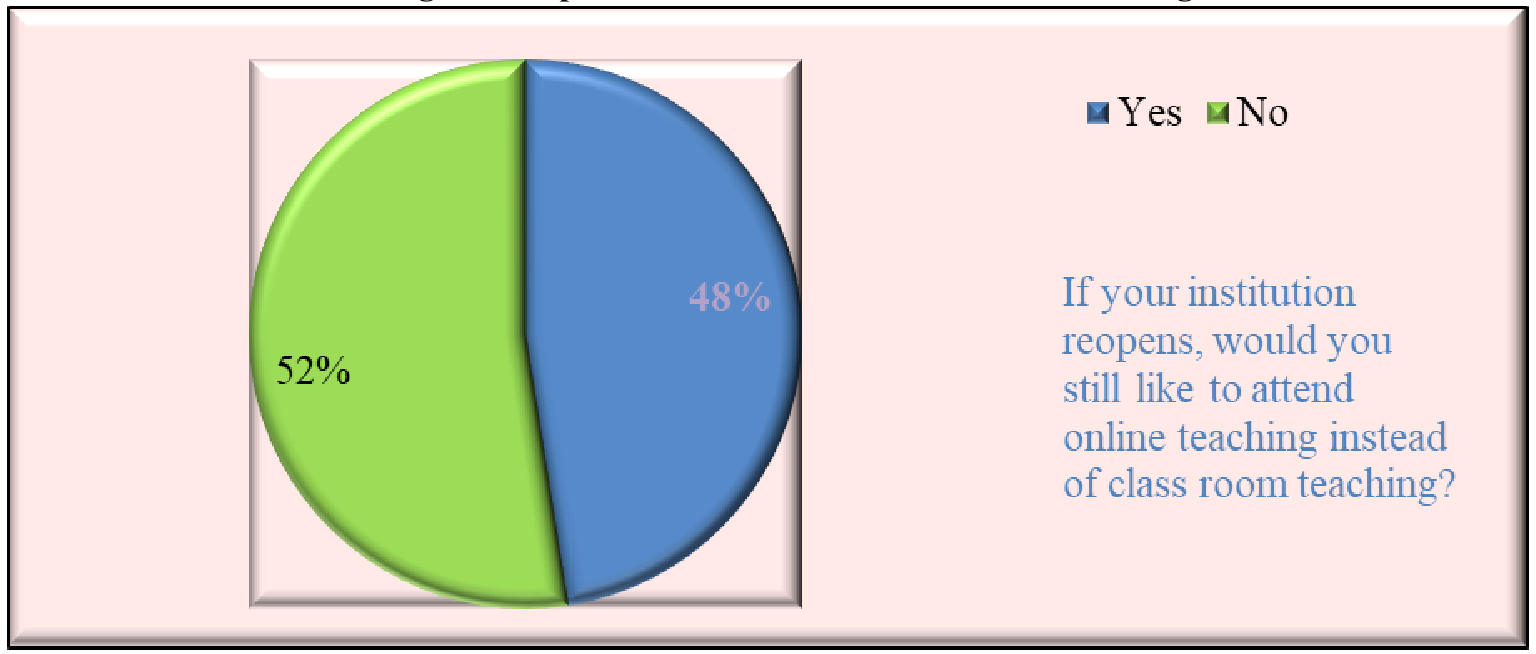

\section{Source: Own estimates from tabulated data}

The above Figure is a clear indicator that there exist a $52: 48$ ratio, where the majority i.e. 52 percent of the total samples (total number of student's response) wish to attain class room teaching instead of online teaching.

\subsection{Statistical analysis:}

Ho1: $_{\text {: }}$ There is no relationship between the area where the students stays and the availability of the online class facilities.

\begin{tabular}{|c|c|c|c|c|c|}
\hline \multicolumn{6}{|c|}{ Table 1: Chi-Square Tests } \\
\hline & Value & $\mathrm{df}$ & $\begin{array}{c}\text { Asymptotic } \\
\text { Significance (2-sided) }\end{array}$ & $\begin{array}{l}\text { Exact Sig. (2- } \\
\text { sided) }\end{array}$ & $\begin{array}{l}\text { Exact Sig. (1- } \\
\text { sided) }\end{array}$ \\
\hline Pearson Chi-Square & $3.75^{\mathrm{a}}$ & 1 & .05 & & \\
\hline Continuity Correction $^{b}$ & 3.26 & 1 & .07 & & \\
\hline Likelihood Ratio & 3.67 & 1 & .05 & & \\
\hline Fisher's Exact Test & & & & .06 & .03 \\
\hline $\begin{array}{l}\text { Linear-by-Linear } \\
\text { Association }\end{array}$ & 3.74 & 1 & .05 & & \\
\hline $\mathrm{N}$ of Valid Cases & 345 & & & & \\
\hline
\end{tabular}

Source: Own estimates from tabulated data 
The above table represents the result of Chi-Square test of association of attributes between the area where the students stays and the availability of the online class facilities by them. Several Statistics are reported here but the most commonly used is the Pearson Chi-Square. In Table 1 the p-Value is equivalent to 0.05 . Therefore, the null hypothesis is rejected. In other words, there seems to be a relationship between area where the students stays and the availability of the online class facilities by them at $95 \%$ level of confidence.

$\mathbf{H}_{02}$ : There is no relationship between the internet connection and the availability of online class facilities.

\begin{tabular}{|l|c|c|c|}
\hline \multicolumn{5}{|c|}{ Table 2: Chi-Square Tests } \\
\hline & Value & $\mathrm{df}$ & Asymptotic Significance (2-sided) \\
\hline Pearson Chi-Square & $40.20^{\mathrm{a}}$ & 4 & $\mathbf{. 0 0}$ \\
\hline Likelihood Ratio & 38.99 & 4 & .00 \\
\hline Linear-by-Linear Association & 31.06 & 1 & .00 \\
\hline N of Valid Cases & 345 & & \\
\hline
\end{tabular}

\section{Source: Own estimates from tabulated data}

The above table presents the result of Chi-Square test of association of attributes between the internet connection of a particular area a student resides and the availability of online class facility by them. Several Statistics are reported here but the most commonly used is the Pearson Chi-Square. In Table 2 the p-Value is less than 0.05 . Therefore, the null hypothesis is rejected. In other words, there seems to be a relationship between the internet connection of a particular area a student resides and the availability of online class facility by them at $95 \%$ level of confidence.

Ho3: There is no relationship between the opinions of students regarding the online class facilities and the availability of online class facilities.

\begin{tabular}{|l|c|c|c|}
\hline \multicolumn{5}{|c|}{ Table 3: Chi-Square Tests } \\
\hline & Value & df & Asymptotic Significance (2-sided) \\
\hline Pearson Chi-Square & $72.44^{\mathrm{a}}$ & 4 & .00 \\
\hline Likelihood Ratio & 71.18 & 4 & .00 \\
\hline Linear-by-Linear Association & 62.99 & 1 & .00 \\
\hline N of Valid Cases & 345 & & \\
\hline a. 0 cells $(0.0 \%)$ have expected count less than 5. The minimum expected count is 8.87. \\
\hline
\end{tabular}

a. 0 cells $(0.0 \%)$ have expected count less than 5 . The minimum expected count is 8.87 .

\section{Source: Own estimates from tabulated data}

The above table represents the result of Chi-Square test of association of attributes between the opinions of students regarding the online class facility and the availability of such facility by them. Several Statistics are reported here but the most commonly used is the Pearson Chi-Square. In Table 3 the p-Value is less than 0.05. Therefore, the null hypothesis is rejected. In other words, there seems to be a relationship between the opinions of students regarding the online class facility and the availability of such facility by them at $95 \%$ level of confidence.

\section{Conclusion}

The viewpoints that the we wanted to project or the objectives with which we started the research work is fulfilled. Hence the study concludes that the students of the urban areas are more benefitted in terms of availing of online classes during the Lockdown than the students of the rural areas. It also reveals from the analysis that internet connection played an important role in case of availing online class facilities i.e. students with proper internet connection were in an advantageous position than the ones who lacked such a proper connection. It is also quite clear that the students availing the online classes are of the opinion that such classes proved to be very effective for them.

Apart from graphical and statistical, presentation, questionnaire thrown to several college students in different parts of the country-either urban or rural- the suggestions that we have obtained from the students front are novel as well as unique in nature. A major part of our sampled respondents (students) suggested that adequate precautionary measures should be taken by the concerned educational institutions in particular and by the government in general before opening up the such institutions. The respondents also suggested that a change in the total infrastructure of such institutions, in syllabus and examination pattern should be made to alleviate the mental agony and distress that they have undergone during lockdown. Many of the respondents opposed online examinations due to lack of proper gadgets and other facilities that are required for a proper online communication. Also, many of the suggestions reflected student's confusion regarding the examination dates and examination syllabus. But above all, it was quiet satisfactory to see that many literally urged for an examination (after having a revised syllabus, proper classes on such syllabus and a proper medium of communication that could be availed by all to determine their own worth. Further studies need to be conducted to cover several other aspects also. We would conclude with the note of optimism that new ray of hope will wake up in the sky of 
educational system in India as well as throughout entire world where students, pandemic aftermath, will learn through online mode of education, a new line of education system, without having access of their respective educational intuitions and complete multiple courses in single academic period.

\section{REFERENCES:}

- Bag, Abhijeet (2018). An Empirical Analysis on the Working Condition of Contractual Teachers in Higher Education Institutions (HEIs) in India with Reference to Selected Government Aided Colleges at Kolkata City of West Bengal. Journal of Education and Practice with ISSN 2222-288X, 9(19), pp37-46.

- Choudhury, S., Jha, M. K., \& Pathak, K. R. (2020). An Empirical Study of The Financial Impact of Covid19on The Tourism Industry in India. Purakala with ISSN 0971-2143 is an UGC CARE Journal, 31(26), pp246-255.

- Kolte, M. V. V. (2020). A Study on Challenges Faced by Employees for Work from Home in Mumbai Region during Lock Down Period of Covid-19. Purakala with ISSN 0971-2143 is an UGC CARE Journal, 31(31), pp233-245.

- Prasad, K. D. V., \& Vaidya, R. W. (2020). Association among Covid-19 parameters, occupational stress and employee performance: An empirical study with reference to Agricultural Research Sector in Hyderabad Metro. Sustainable Humanosphere, 16(2), pp235-253.

- Shaikh, A., \& Mishra, K. (2020). The Impact of the Lockdown on India's Informal Sector. Studies in Indian Place Names, 40(68), pp519-523.

- Shukla, A., \& Kumar, S. (2020). Coping with stress during COVID-19 lockdown. Tathapi with ISSN 23200693 is an UGC CARE Journal, 19(6), pp206-210.

- $\quad$ Singh, M. K., \& Kumar, V. (2020) Impact of Covid-19 Pandemic on Working Culture: An Exploratory Research Among Information Technology (IT) Professionals in Bengaluru, Karnataka (India). Journal of Xi'an University of Architecture \& Technology with ISSN 1006-7930, 12(5), pp3176-3184.

${ }^{i}$ Coronavirus disease 2019 (COVID - 19), Situation Report - 94 by World Health Organisation

ii bbc.com 14 April 2020

iiiwww.nationalgeographic.com/history/2020/04/june

${ }^{i v}$ https://timesofindia.indiatimes.com, $10^{\text {th }}$ May 2020.

Acknowledgement:

[The authors are thankful to their respected teacher, Dr. Sarbapriya Ray, Associate Professor of Commerce, Vivekananda College, Thakurpukur, Kolkata and Guest faculty in the Dept of Commerce, University of Calcutta, Kolkata, India for reviewing the earlier draft of the article. However, the opinions, ideas, explanations, suggestions reflected in the article are solely of the authors and, in no way, of the institutions where they serve or conduct their research study] 